\title{
Methane Emission from Pineapple Cultivation on a Tropical Peatland at Saratok, Malaysia
}

\author{
Liza Nuriati Lim Kim Choo ${ }^{1} \&$ Osumanu H. Ahmed ${ }^{2,3}$ \\ ${ }^{1}$ Malaysian Agricultural Research and Development Institute, MARDI Kuching, Lot 411, Block 14, Santubong \\ Road, 93055 Petra Jaya, Kuching, Sarawak, Malaysia \\ ${ }^{2}$ Department of Crop Science, Faculty of Agriculture and Food Science, Universiti Putra Malaysia, Bintulu \\ Campus, P.O. Box 396, 97008 Bintulu, Sarawak, Malaysia \\ ${ }^{3}$ Institute of Tropical Agriculture and Food Security, Universiti Putra Malaysia, 43400 Serdang, Selangor, \\ Malaysia \\ Correspondence: Osumanu H. Ahmed, Department of Crop Science, Faculty of Agriculture and Food Science, \\ Universiti Putra Malaysia, Bintulu Campus, P.O. Box 396, 97008 Bintulu, Sarawak, Malaysia. E-mail: \\ osumanu@upm.edu.my
}

\author{
Received: October 19, 2016 Accepted: January 18, 2017 Online Published: June 19, 2017 \\ doi:10.5539/sar.v6n3p64 \\ URL: https://doi.org/10.5539/sar.v6n3p64
}

\begin{abstract}
Information on methane emission in pineapple cultivation on peatlands is scarce. Methane emission in pineapple cultivation is important as $90 \%$ of pineapples are grown on the peat soils of Malaysia. It is essential to determine methane emission in pineapple cultivation because pineapples are Crassulacean acid metabolism plants whose effects on methane could be different from other crops grown on tropical peat soils. Methane emissions from root respiration, microbial respiration, and oxidative peat decomposition were determined in a lysimeter experiment. There were three treatments: peat soil cultivated with pineapple, bare peat soil, and bare peat soil fumigated with chloroform. Methane emissions from peat soil cultivated with pineapple, bare peat soil, and bare peat soil fumigated with chloroform were $0.65 \mathrm{t} / \mathrm{ha} / \mathrm{yr}, 0.75 \mathrm{t} / \mathrm{ha} / \mathrm{yr}$, and $0.75 \mathrm{t} / \mathrm{ha} / \mathrm{yr}$, respectively. The lower methane emissions are consistent with the general believe that methane emission from cultivated peat soils is lower than those of anaerobic or water logged peat soils. Soil methane emission was affected by nitrogen fertilization under pineapple cultivation but the converse was true for soil temperature nor soil moisture.
\end{abstract}

Keywords: greenhouse gases, land degradation, lysimeter, organic soils management, peat soil

\section{Introduction}

Tropical peatlands cover approximately 27.1 million hectares in Southeast Asia (Hoojier et al., 2010) out of which 2.6 million hectares of these soils are located in Malaysia (Ismail \& Jamaludin, 2007). Due to the increasing demand for land, peat soils have been encroached on, deforested, and drained for large-scale cultivation of crops such as oil palm (Elaeis guineensis), pineapple (Ananas comosus (L.) Merr.), and sago (Metroxylan sagu). At present, approximately 600,000 hectares of the peat soil in Malaysia are cultivated with oil palm, pineapple, rubber, and sago (Ismail, 2008).

Tropical peat soils are soils formed through the accumulation of partially decayed woody plant materials under waterlogged condition. In their natural state, tropical peats emit methane $\left(\mathrm{CH}_{4}\right)$. Both disturb and undisturbed peatlands are sources of atmospheric $\mathrm{CH}_{4}$. Methane is produced during microbial decomposition of organic matter under anaerobic condition (International Atomic Energy Agency [IAEA], 1992). Tropical peat soils are waterlogged under natural condition. This condition restricts diffusion of atmospheric oxygen into peats. This inhibits microbial decomposition of organic materials (Chimner \& Cooper, 2003). Hence, microorganism are not able to metabolize organic matter into $\mathrm{CO}_{2}$ instead, anaerobic degradation of carbon is carried out by methanogens to produce $\mathrm{CH}_{4}$ (Parmentier, van der Molen, de Jeu, Hendriks, \& Dolman, 2009).

Methane production in the anaerobic layer occurs in the form of dissolved species or as bubbles. Methane is released into the atmosphere through: molecular diffusion (peat pore spaces), ebullition (a process where bubbles in gas are formed from a dissolved state in water and channel their way to surface to the atmosphere) at the water table interface, and vascular plants with aerenchymous porous tissues which transport gases through plant roots 
into the atmosphere (Dinsmore, Skiba, Billett, \& Rees, 2009; Watanabe, Purwanto, Ando, Kakuda, \& Jong, 2009; Farmer, Matthews, J. Smith, P. Smith, \& Singh, 2011; Zhang \& Jiang, 2014). Methane can also be emitted through non-microbial $\mathrm{CH}_{4}$ production from soil organic matter under favorable conditions such as high temperature, UV radiation, and reactive oxygen species (B. Wang, Hou, Liu, \& Z. Wang, 2013).

Drainage that causes water level drawdown of peat soil following land clearing for agriculture accelerates peat decomposition. Decomposition and cultivation of peats have been associated with the release of $\mathrm{CH}_{4}$ into the atmosphere (Hadi et al., 2005; Dinsmore et al., 2009; Watanabe et al., 2009). Currently, concerns about how these anthropogenic activities in tropical peats affect the balance of greenhouse gases such as $\mathrm{CH}_{4}$ in the atmosphere and their role in environmental degradation vis a vis climate change have been expressed (Couwenberg, 2011). Drained tropical peatlands emit low $\mathrm{CH}_{4}$ through microbial processes during which $\mathrm{CH}_{4}$ produced at the saturated layer (interface or beneath the water table) is oxidized at the unsaturated soil into $\mathrm{CO}_{2}$ by methanotrophs (Parmentier et al., 2009; Pandey, J. Singh, D. Singh, \& R. Singh, 2014). Methane emission in tropical peatlands is influenced by water table (Moore \& Dalva, 1993), soil temperature (Nyakanen, Alm, Lang, Silvola, \& Martikainen, 1995; Hargreaves \& Fowler, 1998), and fertilization (Watanabe et al., 2009; Jassal, Black, Roy, \& Ethier, 2011).

Methane emission through vascular plant mediated transport is significant (Watanabe et al., 2009). Presently, there is dearth of information on soil $\mathrm{CH}_{4}$ emission from pineapple cultivation on drained peat soils. The contribution of pineapple cultivation on peats to greenhouse gases emission is important as $90 \%$ of pineapples are grown in the peat soils of Malaysia (Raziah \& Alam, 2010). Most $\mathrm{CH}_{4}$ emission studies on drained peats are limited to paddy, rice-soybean, and sago (Inubushi, Furukawa, Hadi, Purnomo, \& Tsuruta, 2003; Hadi et al., 2005; Watanabe et al., 2009). Furthermore, most $\mathrm{CH}_{4}$ measurements only account for total soil $\mathrm{CH}_{4}$ emission. To date, little is known on the effects of root respiration, microbial respiration, and oxidative peat decomposition to $\mathrm{CH}_{4}$ emission. Therefore, with the growing concern about the effects of greenhouse gases on the environmental quality and the need to achieve sustainable agriculture, it is important to determine the contribution of root respiration, microbial respiration and oxidative peat decomposition to $\mathrm{CH}_{4}$ emission before deciding whether cultivated or degraded peats are net sinks or net sources of atmospheric greenhouse gases. Failure to account for $\mathrm{CH}_{4}$ emission from cultivated peats could underestimate future rates of increase in the atmospheric greenhouse gases. Hence, it is important to quantify and evaluate $\mathrm{CH}_{4}$ emissions from pineapple cultivation on tropical peat soils. Moreover, pineapple is considered a unique plant as it is classified as $\mathrm{C} 3$ and $\mathrm{C} 4$ plant or Crassulacean Acid Metabolism (CAM) plant (Mohammed Selamat, 1996) and because of this, the cultivation of this plant on peat soils could affect $\mathrm{CH}_{4}$ emission.

The general objective of this study was to quantify $\mathrm{CH}_{4}$ emission from a cultivated tropical peat soil. The specific objectives were to determine the: (i) emission of $\mathrm{CH}_{4}$ from root respiration, microbial respiration, and oxidative peat decomposition and (ii) effects of soil temperature and soil moisture on soil $\mathrm{CH}_{4}$ emission.

\section{Materials and Methods}

\subsection{Site Description}

The study was carried out at the Malaysian Agricultural Research and Development Institute (MARDI) Peat Research Station at Saratok, Sarawak, Malaysia from March 2012 to July 2013. The MARDI Peat Research Station at Saratok, Sarawak, Malaysia has a total area of 387 hectares located on a logged-over forest with a flat topography of 5 to $6 \mathrm{~m}$ above mean sea level. Based on the Von Post Scale of $\mathrm{H} 7$ to H9, the peat soil is classified as well decomposed dark brown to almost dark coloured sapric peat with a strong smell. The thickness of the peat soil ranges from 0.5 to $3.0 \mathrm{~m}$. The peat soil is acidic with a mean $\mathrm{pH}$ ranging from 3.4 to 4.0 . It has an average organic carbon content of $47 \%$. The mean temperature of the research station ranges from 22.1 to $31.7^{\circ} \mathrm{C}$. The relative humidity of the area also ranges from 61 to $98 \%$ throughout the year. The annual mean rainfall of the peat area is $3749 \mathrm{~mm}$. During the wet season (November to January), the monthly rainfall is more than 400 $\mathrm{mm}$ but during the dry season particularly in July, the mean rainfall is $189 \mathrm{~mm}$.

\subsection{Soil Chemical and Physical Analysis}

Soil samples were collected at a peat excavation site $(0.5$ hectares $)$ located at the research station. The experimental area was planted with Moris pineapple from 2004 to 2005, after which it was abandoned to lie fallow for six years. Soil samples were taken at depths of 0-20 cm, 20-40 cm, and 40-60 cm systematically in 12 points located over a $20 \mathrm{~m} \times 12.5 \mathrm{~m}$ grid. The soil samples were analyzed for $\mathrm{pH}$, conductivity, ammonium-N, nitrate-N, organic carbon, total nitrogen, and cation exchange capacity (CEC). Soil pH and conductivity were measured based on a 1:5 ratio soil to water suspension (Ismail, Asing, \& Zulkefli, 2007). Ammonium-N and nitrate-N were determined using steam distillation (Bremner \& Keeney, 1966). Soil organic carbon was 
determined using the Walkley and Black method (Nelson \& Sommers, 1982) whereas total nitrogen was determined using the Kjeldahl method (Bremner, 1960). Cation exchange capacity was determined using the Harada and Inoko method (Harada \& Inoko, 1980). Bulk density of the peat soil was determined using the core method (Lim, 1991), and soil water holding capacity was determined using the method of Dugan, Verhoef, Robinson, and Saran (2010).

\subsection{Characteristics of Lysimeters}

Twelve cylindrical field lysimeters made from high density polyethylene, measuring $1.43 \mathrm{~m}$ in diameter and 1.58 $\mathrm{m}$ in height were set up in April 2012 to mimic the natural condition of drained tropical peats. The size of the lysimeters used in this study was to ensure satisfactory growth and development of pineapples for sixteen months. Twelve lysimeters were used for the three peat soil $\mathrm{CH}_{4}$ emission treatments. The lysimeters were equipped with water spillage opening which was attached to tubes mounted on the outside of the vessel to regulate and monitor water level.

Each lysimeter was filled with peat soil up to $120 \mathrm{~cm}$ depth. Water loss from the soil was replenished by showering each lysimeter with 34.5 litres of rainwater. The amount of rainwater applied was based on the volume of the fabricated lysimeter and the mean annual rainfall at Saratok, Sarawak, Malaysia. The lysimeters with the peat soil were left in the open for five months to ensure that the peat soil had settled before the commencement of this study. The duration of this initial phase was based on weekly determination of the peat subsidence. The equilibrium state was achieved in September 2012 before carrying out the $\mathrm{CH}_{4}$ measurement. Throughout the study, the water table of the peat was maintained at 50 to $60 \mathrm{~cm}$ from the soil surface.

\subsection{Peat Soil $\mathrm{CH}_{4}$ Emission Treatments}

The treatments involved in this field lysimeter experiment were as follows: peat soil cultivated with pineapple (A), bare peat soil (B), and bare peat soil treated with chloroform (C). Each treatment had four replications. The treatments were arranged in completely randomized design.

Treatment A represents the total amount of $\mathrm{CH}_{4}$ emitted from root respiration, microbial respiration, and peat decomposition. For this treatment, three Moris pineapple suckers were carefully planted in the lysimeters at a distance of $30 \mathrm{~cm}$. The pineapples were managed by following standard agronomic practices for pineapple cultivation on peats (Mohammed Selamat \& Abdul Rahman, 1996). Treatment B represents $\mathrm{CH}_{4}$ emitted by microbial respiration and peat decomposition. Weed sprouting on the soil surface was controlled when necessary. Treatment $\mathrm{C}$ represents $\mathrm{CH}_{4}$ emitted by oxidative peat decomposition. For this treatment, concentrated chloroform (64.6 litres) was applied evenly on the soil surface to eliminate microbial respiration. The amount of the chloroform used was based on the peat soil's water holding capacity. After the chloroform application, the soil was covered with cling film and canvas followed by securing it with heavy duty tape and aluminium seal lock to produce a vacuum-like condition in the lysimeters to minimize chloroform volatilization. Initial laboratory test was carried out to determine the biocidal effect of the chloroform on bacteria, fungi, and actinomycetes at one, two, three, and four weeks after chloroform application to obtain the optimum time for the chloroform application. The soil microbial population before and after the chloroform volatilization application was determined using the culture method. With this method, bacteria, fungi, and actinomycetes were enumerated as colony forming units (CFU) per gram fresh soil on nutrient agar, Rose Bengal, and actinomycetes isolation agar, respectively (Suhaimi, Emmyrafedziawati, Umi Kalsom, Sahilah, \& Ismail, 2007). The chloroform was used to fumigate the peat soil one week before the soil $\mathrm{CH}_{4}$ measurement was commenced (optimum time interval achieved for the biocidal effect on soil microorganisms).

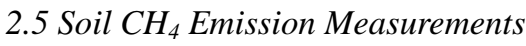

Methane emissions from the field lysimeters were measured using the closed chamber method (IAEA, 1992). Square shape closed chambers with a hollow base and sharp edges were fabricated using acrylic material measuring $20 \mathrm{~cm}$ (width) $\times 20 \mathrm{~cm}$ (height) $\times 20 \mathrm{~cm}$ (length). The top of the chamber was fitted with two sampling ports plugged with rubber septum for gas sampling and thermometer installation, respectively. A battery-operated fan was also attached to the chamber to allow equilibrium gas pressure in and outside the closed chamber. The fabricated chamber was inserted vertically into the soil to a depth of $6.0 \mathrm{~cm}$ and care was taken to avoid disturbance to the surrounding soil. The chamber was covered with aluminium foil to minimize the effect of temperature difference within and outside the chamber.

Extracted gas samples from the chamber were analyzed for $\mathrm{CH}_{4}$ using gas chromatography (Agilent $7890 \mathrm{~A}$ ) equipped with flame ionization detector (FID). The $\mathrm{CH}_{4}$ results were based on the measured $\mathrm{CH}_{4}$ from treatments $\mathrm{A}, \mathrm{B}$, and $\mathrm{C}$ in the wet and dry seasons. The values were averaged and converted into units of $\mathrm{t} / \mathrm{ha} / \mathrm{yr}$. 
The gas flux was calculated from the increase in the chamber concentration over time using the chamber volume and soil area covered, using the following equation (IAEA, 1992; Widen \& Lindroth, 2003; Zulkefli, Lim Kim Choo, \& Ismail, 2010):

$$
\text { Flux }=\left[d\left(\mathrm{CH}_{4}\right) / d t\right] x \text { PV/ART }
$$

where $d\left(\mathrm{CH}_{4}\right) /(d t)$ is the evolution rate of $\mathrm{CH}_{4}$ within the chamber headspace at a given time after putting the chamber into the soil, $P$ is the atmospheric pressure, $V$ is the volume headspace gas within the chamber, $A$ is the area of soil enclosed by the chamber, $R$ is the gas constant, and $T$ is the air temperature.

The gas flux was measured in the early morning (2.40 a.m. to 5.55 a.m.), morning (7.15 a.m. to 10.30 a.m.), mid-morning to afternoon (10.35 a.m. to 1.50 p.m.), afternoon (1.55 p.m. to 5.10 p.m.), evening ( 8.00 p.m. to 11.15 p.m.), and night (11.20 p.m. to 2.35 a.m.). The flux measurements were carried out in September 2012, November 2012, and January 2013 to represent the concentrations of $\mathrm{CH}_{4}$ in the wet season whereas April 2013 and July 2013 flux measurements represent the concentrations of $\mathrm{CH}_{4}$ in the dry season. Soil temperature and moisture were measured using Eijkelkamp IP68 and ML3 sensors, respectively. Rainfall, temperature, and air humidity data were also recorded using a portable weather station (WatchDog 2900) installed at the experimental site.

\subsection{Statistical Analysis}

Treatment effects were tested using analysis of variance (ANOVA) whereas means of treatments were compared using Duncan's New Multiple Range Test at $\mathrm{p} \leq 0.05$. The relationships between $\mathrm{CH}_{4}$ emission, soil temperature, and soil moisture were analyzed using Pearson correlation analysis. The statistical software used for these statistical analyses was the Statistical Analysis System (SAS) Version 9.1.

\section{Results}

\subsection{Peat Physical and Chemical Properties}

Results of peat soil properties were compared with the previously reported ranges (Table 1) for tropical peats in Southeast Asia (Andriesse, 1988) and Malaysia (Andriesse, 1988; Malaysian Agricultural Research and Development Institute [MARDI], 1996; Murtedza, Padmanabhan, Mei, \& Siong, 2002). The bulk density of the peat soil at $10 \mathrm{~cm}$ ranged from 0.09 to $0.18 \mathrm{~g} / \mathrm{cm}^{3}$ whereas water holding capacity of the peat soil was $40.2 \%$. Soil moisture increased with increasing depth. Values of $\mathrm{pH}$, conductivity, CEC, total organic carbon, and total nitrogen of the peat soil are within the reported range (Andriesse, 1988; MARDI, 1996; Murtedza et al., 2002; STRAPEAT, Universiti Malaysia Sarawak [UNIMAS], \& National Resources and Environment Boards [NREB], 2004). The soil chemical properties showed no significant difference with depth except for total nitrogen, ammonium- $\mathrm{N}$, and nitrate- $\mathrm{N}$. The total nitrogen of the soil was high. The total nitrogen ranged from 1.1 to $1.3 \%$. Ammonium- $\mathrm{N}$ ranged from 94.8 to $138.5 \mathrm{mg} / \mathrm{L}$ whereas nitrate- $\mathrm{N}$ ranged from 48.8 to $72.0 \mathrm{mg} / \mathrm{L}$ at the three soil depths.

Table 1. Physical and chemical properties of a drained peat soil sampled at different depths

\begin{tabular}{|c|c|c|c|c|c|}
\hline \multirow{2}{*}{ Variable } & \multirow{2}{*}{ Mean $(0$ to $10 \mathrm{~cm})$} & \multicolumn{3}{|c|}{ Results per soil depth (cm) } & \multirow{2}{*}{ Reported range } \\
\hline & & 0 to $20 \mathrm{~cm}$ & 20 to $40 \mathrm{~cm}$ & 40 to $60 \mathrm{~cm}$ & \\
\hline \multicolumn{6}{|c|}{ Physical properties } \\
\hline Bulk density $\left(\mathrm{g} / \mathrm{cm}^{3}\right)$ & 0.14 & & & & 0.09-0.12 (Andriesse, 1988) \\
\hline $\begin{array}{l}\text { Water holding } \\
\text { capacity }(\%)\end{array}$ & 40.2 & & & & 275-322 (Andriesse, 1988) \\
\hline Moisture (\%) & & $80.9^{\mathrm{c}}$ & $84.9^{\mathrm{b}}$ & $88.8^{\mathrm{a}}$ & 90-95 (Murtedza et al., 2002) \\
\hline \multicolumn{6}{|c|}{ Chemical properties } \\
\hline $\mathrm{pH}$ & & $3.8^{\mathrm{a}} \pm 0.1$ & $3.9^{\mathrm{a}} \pm 0.1$ & $3.9^{\mathrm{a}} \pm 0.1$ & 3.0-4.5 (Andriesse, 1988) \\
\hline Conductivity $(\mu \mathrm{S} / \mathrm{cm})$ & & $178.5^{\mathrm{a}} \pm 4.6$ & $175.4^{\mathrm{a}} \pm 4.3$ & $172.7^{\mathrm{a}} \pm 2.4$ & < 200 (MARDI, 1996) \\
\hline Cation exchange & & $146.4^{\mathrm{a}} \pm 20.1$ & $137.6^{\mathrm{a}} \pm 13.7$ & $175.6^{\mathrm{a}} \pm 34.9$ & 200 (Andriesse, 1988) \\
\hline capacity $\left(\mathrm{cmol}_{(+)} / \mathrm{kg}\right)$ & & & & & 145 (MARDI, 1996) \\
\hline Total organic carbon $(\%)$ & & $40.0^{\mathrm{a}} \pm 0.8$ & $39.8^{\mathrm{a}} \pm 1.4$ & $36.5^{\mathrm{a}} \pm 1.1$ & 12-60 (Andriesse, 1988) \\
\hline & & & & & 20.4-38.4 (STRAPEAT et al., 2004) \\
\hline Total nitrogen $(\%)$ & & $1.33^{\mathrm{a}} \pm 0.03$ & $1.18^{\mathrm{b}} \pm 0.04$ & $1.12^{\mathrm{b}} \pm 0.03$ & 1.10-1.67 (Murtedza et al., 2002) \\
\hline Ammonium-Nitrogen(mg/L) & & $138.5^{\mathrm{a}} \pm 16.2$ & $100.0^{\mathrm{b}} \pm 4.2$ & $94.8^{\mathrm{b}} \pm 7.7$ & n.a. \\
\hline Nitrate-Nitrogen $(\mathrm{mg} / \mathrm{L})$ & & $72.0^{\mathrm{a}} \pm 5.4$ & $48.8^{\mathrm{b}} \pm 6.3$ & $65.8^{\mathrm{ab}} \pm 3.0$ & n.a. \\
\hline
\end{tabular}

Values (mean \pm standard error) with different letter across the column are significantly different at $\mathrm{p} \leq 0.05$.

n.a. = not available 


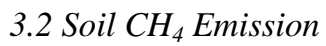

Methane emissions under treatments $\mathrm{A}, \mathrm{B}$, and $\mathrm{C}$ varied in the wet and dry seasons (Figure 1). In the wet season, the $\mathrm{CH}_{4}$ emission under treatment $\mathrm{C}$ was significantly higher than those of treatments $\mathrm{A}$ and $\mathrm{B}$. However, in the dry season, the $\mathrm{CH}_{4}$ emission under treatment $\mathrm{B}$ was higher, followed by treatment $\mathrm{A}$, and treatment $\mathrm{C}$.

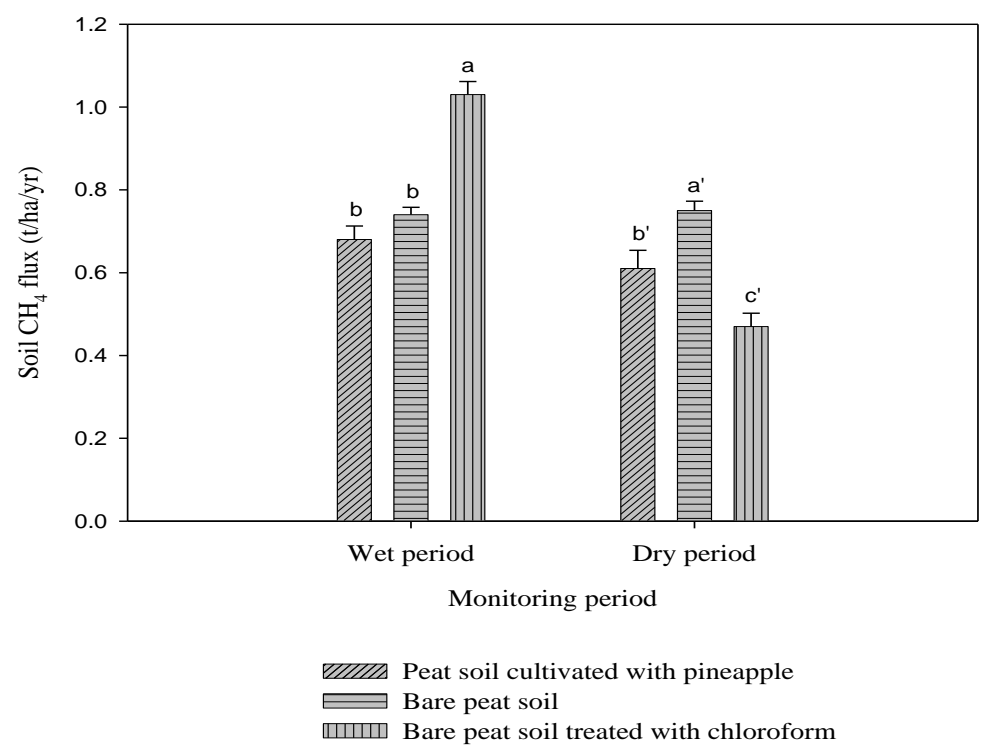

Figure 1. Soil $\mathrm{CH}_{4}$ emission (wet and dry seasons) from peat soil cultivated with pineapple, bare peat soil, and chloroform fumigated peat soil. (Error bars represent standard error and soil mean fluxes with different letters are significantly different at $\mathrm{p} \leq 0.05$ )

The $\mathrm{CH}_{4}$ emission showed no specific trend with time of sampling (Figure 2). The $\mathrm{CH}_{4}$ emission was generally similar in the wet season. In the dry season, the $\mathrm{CH}_{4}$ emission increased from early morning to mid-morning to afternoon. However, the $\mathrm{CH}_{4}$ emissions in the afternoon, evening and night were similar during the wet and dry seasons.

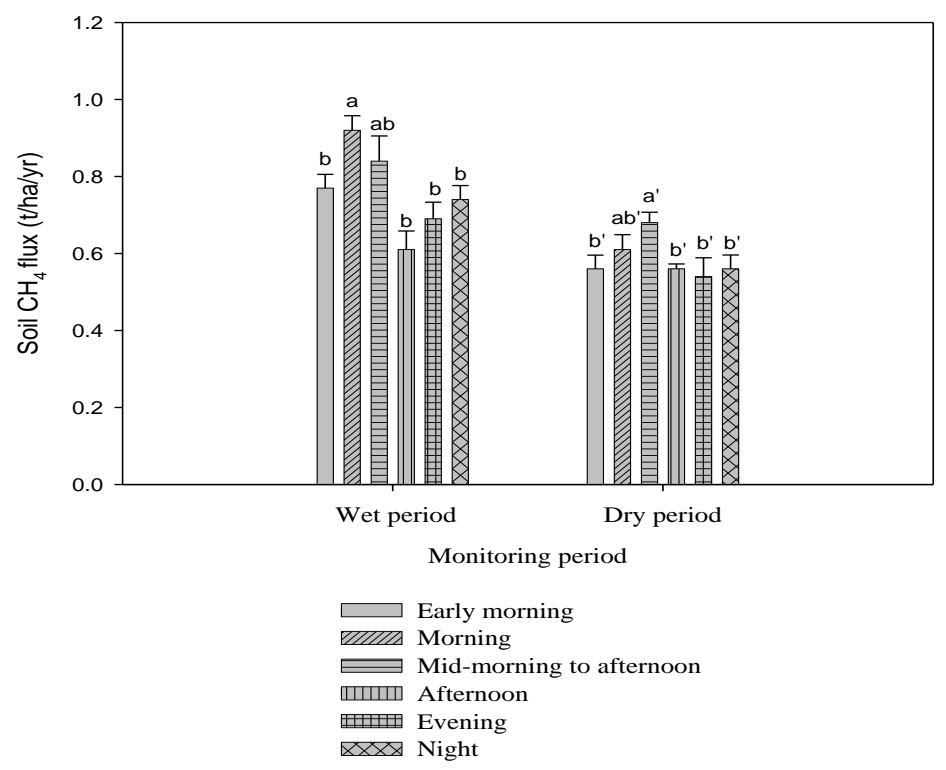

Figure 2. Soil $\mathrm{CH}_{4}$ emission (at different times of the day and different seasons) from drained tropical peat. (Error bars represent standard error and soil mean fluxes with different letters are significantly different at $p \leq 0.05$ ) 


\section{Discussion}

\subsection{Peat Physical and Chemical Properties}

The bulk density of the peat soil is typical of a sapric peat. The bulk density was determined at $10 \mathrm{~cm}$ due to the saturated condition of the excavation site. The water holding capacity was below the reported range because its determination was based on oven-dry weight method (Andriesse, 1988). The increasing moisture content with increasing peat soil depth is related to the high water table at the excavation site. However, removal of trees and debris after land clearing may have accelerated oxidative decomposition. The $\mathrm{pH}$ of the peat soil was low, suggesting a need for liming before being cultivated. The lower conductivity of the peat soil indicates that the soil is not saline as the research station is drained by two large tidal rivers (Sebelak River and Nyabor River). The intrusion of salt water at the station is prevented by a tidal gate constructed at the main outlet leading to Nyabor River. The CEC of the peat soil is high because of lignin-derivates formed during decomposition. Ion exchange in peats is related to carboxyl and phenolic radicals of humic substances and hemicelluloses (Andriesse, 1988). However, the CEC obtained is higher than the reported range (MARDI, 1996). This may be attributed to the past liming activities at the excavation site. This area was cultivated with pineapples from 2004 to 2005. The high organic carbon content is due to the botanical origin (woody) of the sapric peat (Andriesse, 1988; Murtedza et al., 2002). Total nitrogen, ammonium- $\mathrm{N}$, and nitrate- $\mathrm{N}$ contents decreased with increasing soil depth (from 0-20 $\mathrm{cm}$ to 20-40 cm depths) because decomposition of peats generally decreases (low oxidation with increasing water content) down the soil profile (Andriesse, 1988). Furthermore, tropical peats are generally higher in lignin but lower in cellulose. Microbes decompose cellulose easily thus, leaving behind the resistant lignin as the peat decomposes thereby increasing nitrogen content.

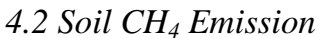

Soil $\mathrm{CH}_{4}$ emission under treatment $\mathrm{A}$ was affected by the availability of electron acceptors particularly nitrate from the fertilization (Jassal et al., 2011; Sirin \& Laine, 2012). This observation is consistent with the fertilizer applications at 4.5 and 9 months old of the pineapple plants in September 2012 and January 2013, respectively (Table 2). The fertilizers applied were foliar and compound fertilizers that had urea and ammonium sulfate. These fertilizers might have increased nitrate content of the soil. Nitrate is water soluble such that leaches to the anoxic layer to inhibit $\mathrm{CH}_{4}$ production (Jassal et al., 2011; Sirin \& Laine, 2012). The shallow roots of the pineapple plants and depth of the water table in the lysimeter might have restricted $\mathrm{CH}_{4}$ emission through vascular plant-mediated transport (Dinsmore et al., 2009).

Table 2. Fertilizer management for pineapple cultivation on a drained tropical peat soil

\begin{tabular}{|c|c|c|c|}
\hline \multirow{2}{*}{ Months after planting } & \multirow{2}{*}{ Activities } & \multicolumn{2}{|l|}{ Fertilizer description } \\
\hline & & Type & Rate \\
\hline $\begin{array}{c}1.5 \text { months } \\
\text { (05 June 2012) }\end{array}$ & $\begin{array}{l}\text { First foliar fertilizer } \\
\text { application }\end{array}$ & $\begin{array}{l}\text { Mixture of copper sulfate }(42 \mathrm{~g}) \text {, iron sulfate }(21 \mathrm{~g}) \text {, } \\
\text { zinc sulfate }(42 \mathrm{~g}) \text { and lime }(640 \mathrm{~g}) \text { dissolved in } 18 \\
\text { litres of water. }\end{array}$ & $50 \mathrm{~mL}$ per plant \\
\hline 3 months (19 July 2012) & $\begin{array}{l}\text { First compound } \\
\text { fertilizer application }\end{array}$ & $\begin{array}{l}\text { A } 100 \mathrm{~kg} \text { of compound fertilizer is a mixture of } 72 \mathrm{~kg} \\
\text { of ammonium sulfate, } 1 \mathrm{~kg} \text { of Christmas island rock } \\
\text { phosphate (CIRP) and } 27 \mathrm{~kg} \text { of muriate potash (MP). }\end{array}$ & $20 \mathrm{~g}$ per plant \\
\hline $\begin{array}{c}4.5 \text { months } \\
\text { (03 September 2012) }\end{array}$ & $\begin{array}{l}\text { Second foliar fertilizer } \\
\text { application }\end{array}$ & $\begin{array}{l}\text { Mixture of copper sulfate }(42 \mathrm{~g}) \text {, iron sulfate }(21 \mathrm{~g}) \text {, } \\
\text { zinc sulfate }(42 \mathrm{~g}) \text {, lime }(640 \mathrm{~g}) \text { and urea }(640 \mathrm{~g}) \\
\text { dissolved in } 18 \text { litres of water. }\end{array}$ & $100 \mathrm{~mL}$ per plant \\
\hline $\begin{array}{l}6 \text { months } \\
\text { (18 October 2012) } \\
9 \text { months } \\
\text { (16 January 2013) }\end{array}$ & $\begin{array}{l}\text { Second compound } \\
\text { fertilizer application } \\
\text { Third compound } \\
\text { fertilizer application }\end{array}$ & $\begin{array}{l}\text { A } 100 \mathrm{~kg} \text { of compound fertilizer is a mixture of } 72 \mathrm{~kg} \\
\text { of ammonium sulfate, } 1 \mathrm{~kg} \text { of Christmas island rock } \\
\text { phosphate (CIRP) and } 27 \mathrm{~kg} \text { of muriate potash (MP). }\end{array}$ & $20 \mathrm{~g}$ per plant \\
\hline
\end{tabular}

The $\mathrm{CH}_{4}$ emission under treatment $\mathrm{B}$ could be attributed to the methanogenic and methanotrophic microorganisms because these organisms are known to be responsible for $\mathrm{CH}_{4}$ production and consumption (Parmentier et al., 2009). The $\mathrm{CH}_{4}$ emission under treatment $\mathrm{B}$ might have been affected by the oxidation of $\mathrm{CH}_{4}$ to $\mathrm{CO}_{2}$ by methanotrophs (Kasimir-Klemedtsson et al., 1997; Kløve, Sveistrup, \& Hauge, 2010).

The $\mathrm{CH}_{4}$ emission under treatment $\mathrm{C}$ was affected by oxidative peat decomposition (shrinkage and consolidation) as the fumigant (chloroform) used inhibited microbial respiration. Bacteria and actinomycetes populations before and after fumigation were statistically similar. Fungi were not detected in this present study. These findings are in agreement with previous findings that had demonstrated that chloroform could effectively kill (94\% to 99\%) microorganisms (Jenkinson and Powlson, 1976; Ingham \& Horton 1987; Dickens \& Anderson, 1999; Toyota, Ritz, \& Young, 1996; Hu \& van Bruggen, 1998). The effectiveness of the fumigation is supported by the 
decrease in the mean soil microbial biomass carbon (Table 3). However, it must be stressed that the lower population of soil microorganisms and reduction in soil microbial biomass carbon after chloroform fumigation does not fully suggest $\mathrm{CH}_{4}$ emission through the inhibition of microbial respiration. The present study failed to consider microbiology bioassays to verify the contribution of microbial respiration (methanogenic and methanotrophic communities) to $\mathrm{CH}_{4}$ emission. The insignificant difference in the peat subsidence rates recorded throughout the duration of this study regardless of treatments suggests that the chloroform used did not affect $\mathrm{CH}_{4}$ emission due to oxidative peat decomposition. This observation corroborates that of Toyota et al. (1996) who also found no significant effect of chloroform fumigation on soil bulk density and compaction.

Table 3. Effect of fumigating drained peat soil with chloroform on soil microbial biomass carbon

\begin{tabular}{ll}
\hline Monitoring cycle & $\begin{array}{l}\text { Mean soil microbial biomass carbon } \\
(\mu \mathrm{g} \mathrm{C} / \mathrm{g} \text { soil })\end{array}$ \\
\hline Initial before chloroform application & $94.7^{\mathrm{a}}$ \\
September 2012 & $29.6^{\mathrm{f}}$ \\
November 2012 & $73.4^{\mathrm{b}}$ \\
January 2013 & $56.0^{\mathrm{d}}$ \\
April 2013 & $67.2^{\mathrm{c}}$ \\
July 2013 & $46.0^{\mathrm{e}}$ \\
\hline
\end{tabular}

Mean values with different letters are significantly different at $\mathrm{p} \leq 0.05$.

It was also possible that the $\mathrm{CH}_{4}$ was emitted from non-microbial production of $\mathrm{CH}_{4}$ sources such as lignin and humic acids (Wang et al., 2013). This might have occurred under moderate temperature fluctuation of the tropics (Table 4) as peats are high in organic matter besides being natural polyelectrolyte with substances such as humic acids, fulvic acids, humin, lignin, and carbohydrate (Helal Udin, Ahmad Sujari, \& Mohd. Nawi, 2003; Allen, McKay, \& Porter, 2004; Zulfikar, Novita, Hertadi, \& Djajanti, 2013).

Table 4. Day and night temperatures of the experimental site (Saratok, Malaysia)

\begin{tabular}{|c|c|c|c|c|c|}
\hline \multirow{2}{*}{ Variable } & \multicolumn{3}{|c|}{ Wet season } & \multicolumn{2}{|c|}{ Dry season } \\
\hline & September 2012 & November 2012 & January 2013 & April 2013 & July 2013 \\
\hline Mean day time temperature $\left({ }^{\circ} \mathrm{C}\right)$ & 26.7 & 29.2 & 29.6 & 26.3 & 27.0 \\
\hline Mean night time temperature $\left({ }^{\circ} \mathrm{C}\right)$ & 23.6 & 24.9 & 24.5 & 24.6 & 24.7 \\
\hline $\begin{array}{l}\text { Mean day and night time temperature } \\
\text { differences }\left({ }^{\circ} \mathrm{C}\right)\end{array}$ & 3.1 & 4.3 & 5.1 & 1.7 & 2.3 \\
\hline \multicolumn{6}{|c|}{ Mean soil temperature $\left({ }^{\circ} \mathrm{C}\right)$} \\
\hline Early morning & $29.8^{\mathrm{a}}$ & $30.0^{\mathrm{bc}}$ & $28.2^{\mathrm{bc}}$ & $30.1^{\mathrm{a}}$ & $28.7^{\mathrm{b}}$ \\
\hline Morning & $30.8^{\mathrm{a}}$ & $32.1^{\mathrm{ab}}$ & $29.8^{\mathrm{a}}$ & $30.5^{\mathrm{a}}$ & $29.5^{\mathrm{b}}$ \\
\hline Mid-morning to afternoon & $30.9^{\mathrm{a}}$ & $32.8^{\mathrm{a}}$ & $30.7^{\mathrm{a}}$ & $30.5^{\mathrm{a}}$ & $30.6^{\mathrm{b}}$ \\
\hline Afternoon & $29.7^{\mathrm{a}}$ & $31.1^{\mathrm{abc}}$ & $30.5^{\mathrm{a}}$ & $29.3^{\mathrm{ab}}$ & $32.6^{\mathrm{a}}$ \\
\hline Evening & $29.5^{\mathrm{a}}$ & $30.1^{\mathrm{bc}}$ & $29.4^{\mathrm{ab}}$ & $28.7^{\mathrm{ab}}$ & $29.2^{\mathrm{b}}$ \\
\hline Night & $29.0^{\mathrm{a}}$ & $29.2^{\mathrm{c}}$ & $27.9^{\mathrm{c}}$ & $27.7^{\mathrm{b}}$ & $28.7^{\mathrm{b}}$ \\
\hline
\end{tabular}

Means with different letter within the same column are significantly different at $\mathrm{p} \leq 0.05$.

Regardless of season, the $\mathrm{CH}_{4}$ emission was not affected by time of sampling and this is not consistent with the significant positive (September 2012) and negative (January 2013 and April 2013) correlations between soil $\mathrm{CH}_{4}$ emission and soil temperature (Table 5). However, the overall data (wet and dry seasons) showed no correlation between $\mathrm{CH}_{4}$ emission and soil temperature (Table 5). These findings also suggest that $\mathrm{CH}_{4}$ emission is not affected by soil temperature because of the moderate fluctuation in soil temperature $\left(0.2\right.$ and $\left.1.6^{\circ} \mathrm{C}\right)$ of the tropics (Table 4). There was no correlation between $\mathrm{CH}_{4}$ emission and soil moisture except in April 2013 (Table 5) because the water table in the lysimeters was maintained at 50 and $60 \mathrm{~cm}$. This finding is further supported by the insignificant correlation of the overall data (wet and dry seasons) between $\mathrm{CH}_{4}$ emission and soil moisture (Table 5). In a related study, Kløve et al. (2010) found that changing temperature and groundwater level had little effect on $\mathrm{CH}_{4}$ emission from cultivated peatlands. 
Table 5. Relationship between soil $\mathrm{CH}_{4}$ emission, soil temperature, and soil moisture in dry and wet seasons

\begin{tabular}{|c|c|c|c|c|}
\hline Weather season & Monitoring period & Variable & Soil temperature & Soil moisture \\
\hline \multirow{3}{*}{ Wet season } & September 2012 & \multirow{6}{*}{ Soil $\mathrm{CH}_{4}$ emission } & $\begin{array}{l}r=0.4589 \\
p=0.0013\end{array}$ & $\begin{array}{l}\mathrm{r}=0.0216 \\
\mathrm{p}=0.8866\end{array}$ \\
\hline & November 2012 & & $\begin{array}{l}r=-0.2196 \\
p=0.1296\end{array}$ & $\begin{array}{l}\mathrm{r}=-0.0908 \\
\mathrm{p}=0.5348\end{array}$ \\
\hline & January 2013 & & $\begin{array}{l}r=-0.3921 \\
p=0.0044\end{array}$ & $\begin{array}{l}r=0.0618 \\
p=0.6665\end{array}$ \\
\hline \multirow{2}{*}{ Dry season } & April 2013 & & $\begin{array}{l}r=-0.4511 \\
p=0.0003\end{array}$ & $\begin{array}{l}\mathrm{r}=-0.3749 \\
\mathrm{p}=0.0034\end{array}$ \\
\hline & July 2013 & & $\begin{array}{l}r=-0.2780 \\
p=0.0784\end{array}$ & $\begin{array}{l}r=-0.0769 \\
p=0.6329\end{array}$ \\
\hline \multicolumn{2}{|c|}{ Pooling data throughout the wet and dry seasons } & & $\begin{array}{l}r=-0.3980 \\
p=0.5344\end{array}$ & $\begin{array}{l}r=-0.0325 \\
p=0.6121\end{array}$ \\
\hline
\end{tabular}

Top values represent Pearson's correlation coefficient (r) while bottom values represent probability level at 0.05 ( $\mathrm{n}=72$ for each monitoring period, $\mathrm{n}=360$ for pooling data throughout wet and dry seasons).

\section{Conclusion}

Peat soils drained for agriculture released $0.65 \mathrm{t} \mathrm{CH}_{4}$ ha/yr under peat soil cultivated with Moris pineapple, and $0.75 \mathrm{t} \mathrm{CH}_{4} \mathrm{ha} / \mathrm{yr}$ under bare peat soil and bare peat soil treated with chloroform, respectively. The soil $\mathrm{CH}_{4}$ emissions were neither affected by soil temperature nor by soil moisture. Soil $\mathrm{CH}_{4}$ emission under peat soil cultivated with pineapples seemed to be affected by nitrate-based fertilization through nitrate electron acceptors by inhibiting $\mathrm{CH}_{4}$ production. Quantification and identification of the ratio of active methanogenic and methanotrophic communities in peat and the possibility of pineapples as plant-mediated $\mathrm{CH}_{4}$ transport may help to further verify whether drained peats are net sources or sinks of $\mathrm{CH}_{4}$. Further research is needed to assess non-microbial $\mathrm{CH}_{4}$ production in peat as this soil contains high organic matter with lignin and humic acids as its major components.

\section{Acknowledgements}

The authors acknowledge the financial support of the Ministry of Education Malaysia through Universiti Putra Malaysia. This research was funded through Research University Grants Scheme (RUGS), Grant number 9324300. The facilities provided by the Malaysia Agricultural Research and Development Institute at MARDI Saratok Peat Research Station for this study is appreciated.

\section{References}

Allen, S. J., McKay, G., \& Porter, J. F. (2004). Adsorption isotherm models for basic dye adsorption by peat in single binary component systems. Colloid and Interface Science, 280, 322-333. https://dx.doi.org/10.1016/j.jcis.2004.08.078

Andriesse, J. P. (1988). The main characteristics of tropical peats. In: Nature and Management of Tropical Peat Soils. FAO Soils Bulletin 59. Rome: FAO.

Bremner, J. M. (1960) Nitrogen-total. In: Sparks D.L., Page A.L., Helmke P.A., Leoppert R.H., Soltanpour P.N., Tabatabai M.A. \& Johnston, C.T. (Eds.), Methods of soil analysis, Part 3, Chemical methods (pp. 1085-1121). Wisconsin, USA: Soil Science Society of America Journal.

Bremner, J. M., \& Keeney, D. R. (1966). Determination and isotope-ratio analysis of different forms of nitrogen in soils. Part 3. Exchangeable ammonium, nitrate and nitrite by extraction-distillation methods. Soil Science Society of America Journal, 30(5), 577-582.

Berglund. Ö., \& Berglund, K. (2011). Influence of water table level and soil properties on emissions of greenhouse gases from cultivated peat soil. Soil Biology and Biochemistry, 43, 923-931. http://dx.doi.org/10.1016/j.soilbio.2011.01.002

Chimner, R. A., \& Cooper, D. J. (2003). Influence of water table levels on $\mathrm{CO}_{2}$ emissions in a Colorado subalpine fen: an insitu microcosm study. Soil Biology and Biochemistry, 35, 345-351. http://dx.doi.org/10.1016/S0038-0717(02)00284-5

Couwenberg, J. (2011). Greenhouse gas emissions from managed peat soils: is the IPCC reporting guidance 
realistic?. Mires and Peat, 8(2), 1-10. International Mire Conservation Group and International Peat Society. Retrieved from http://www.mires-and-peat.net/pages/volumes/map08/map0802.php

Dickens, H. E., \& Anderson, J. M. (1999). Manipulation of soil microbial community structure in bog and forest soils using chloroform fumigation. Soil Biology and Biochemistry, 31, 2049-2058.

http://dx.doi.org/10.1016/S0038-0717(99)00128-5

Dinsmore, K. J., Skiba, U. M., Billett, M. F., \& Rees, R. M. (2009). Effect of water table on greenhouse gas emissions from peatland mesocosms. Plant Soil, 318, 229-242.

http://dx.doi.org/10.1007/s11104-008-9832-9

Dugan, E., Verhoef, A., Robinson, S., \& Saran, S. (2010). Bio-char from sawdust, maize stover and charcoal: Impact on water holding capacities (WHC) of three soils from Ghana. Proceedings of the $19^{\text {th }}$ World Congress of Soil Science: Soil Solutions for a Changing World, Brisbane, Australia, 1-6 August, 2010 pp. 9-12.

Farmer, J., Matthews, R., Smith, J. U., Smith, P., \& Singh, B. K. (2011). Assessing existing peatland models for their applicability for modelling greenhouse gas emissions from tropical peat soils. Current Opinion in Environmental Sustainability, 3, 339-349. http://dx.doi.org/10.1016/j.cosust.2011.08.010

Hadi, A., Inubushi, K., Furukawa, Y., Purnomo, E., Rasmadi, M., \& Tsuruta, H. (2005). Greenhouse gas emissions from tropical peatlands of Kalimantan, Indonesia. Nutrient Cycling in Agroecosystem, 71, 73-80. http://dx.doi.org/10.1007/s10705-004-0380-2

Harada, Y., \& Inoko, A. (1980) The measurement of the cation-exchange capacity of composts for the estimation of the degree of maturity. Soil Science and Plant Nutrition, 26(1), 127-134. http://dx.doi.org/10.1080/00380768.1980.10433219

Hargreaves, K. J., \& Fowler, D. (1998). Quantifying the effects of water tables and soil temperature on the emission of methane from peat wetland at the field scale. Atmospheric Environment, 32(19), 3275-3282. http://dx.doi.org/10.1016/S1352-2310(98)00082-X

Helal Udin, A. B. M., Ahmad, Sujari, A. M., \& Mohd, Nawi, M. A. (2003). Effectiveness of peat coagulant for the removal of textile dyes from aqueous solution and textile wastewater. Malaysian Journal of Chemistry, 5(1), 034-043.

Hoojier, A., Page, S., Canadell, J. G., Silvius, M., Kwadijk, J., Wösten, H., \& Jauhiainen, J. (2010). Current and future $\mathrm{CO}_{2}$ emissions from drained peatlands in Southeast Asia. Biogeoscience, 7, 1505-1514. http://dx.doi.org/10.5194/bg-7-1505-2010

Hu, S., \& Van Bruggen, A. H. C. (1998). Efficiencies of chloroform fumigation in soil: effects of physiological states on bacteria. Soil Biology and Biochemistry, 30(13), 1841-1844. http://dx.doi.org/10.1016/S0038-0717(98)00026-1

International Atomic Energy Agency (1992). Sampling techniques and sample handling. In: Manual on measurement of methane and nitrous oxide emissions from agriculture (pp. 45-67). IAEA-TECDOC-674. Vienna: IAEA.

Ingham, E. R., \& Horton, K. A. (1987). Bacterial, fungal and protozoan response to chloroform fumigation in stored soil. Soil Biology and Biochemistry, 19(5), 545-550. http://dx.doi.org/10.1016/0038-0717(87)90097-6

Inubushi, K., Furukawa, Y., Hadi, A., Purnomo, E., \& Tsuruta, H. (2003). Seasonal changes of $\mathrm{CO}_{2}, \mathrm{CH}_{4}$ and $\mathrm{N}_{2} \mathrm{O}$ fluxes in relation to land-use change in tropical peatlands located in coastal area of South Kalimantan. Chemosphere, 52, 603-608. http://dx.doi.org/10.1016/S0045-6535(03)00242-X

Ismail, A. B., \& Jamaludin, J. (2007). Land clearing techniques employed at MARDI Peat Research Station, Sessang, Sarawak, and their immediate impacts. In: Ismail A.B., Ong H.K., Mohamad Hanif M.J. \& Umi Kalsom M.S. (Eds.), A case study at MARDI Peat Research Station, Sessang, Sarawak, Malaysia (pp. 1-8). Malaysia: MARDI.

Ismail, A. B., Asing, J., \& Zulkefli, M. (2007). Residual impact of various land clearing techniques on peat chemical characteristics. In: Ismail A.B., Ong H.K., Mohamad Hanif M.J. \& Umi Kalsom M.S. (Eds.), A case study at MARDI Peat Research Station, Sessang, Sarawak, Malaysia (pp. 33-61). Malaysia: MARDI.

Ismail, A. B. (2008). Towards wise use of tropical peatland: from agriculture perspective. Proceedings of the International Symposium and Workshop on Tropical Peatland, Kuching, Sarawak, Malaysia, 19-22 August, 
2008 pp. 129-141.

Jassal, R. S., Black, T. A., Roy, R., \& Ethier, G. (2011). Effect of nitrogen fertilization on soil $\mathrm{CH}_{4}$ and $\mathrm{N}_{2} \mathrm{O}$ fluxes, and soil and bole respiration. Geoderma, 162, 182-186. http://dx.doi.org/10.1016/j.geoderma.2011.02.002

Jenkinson, D. S., \& Powlson, D. S. (1976). The effects of biocidal treatments on metabolism in soil - I. Fumigation with chloroform. Soil Biology and Biochemistry, 8, 167-177. http://dx.doi.org/10.1016/0038-0717(76)90001-8

Kasimir-Klemedtsson, A., Klemedtsson, L., Berglund, K., Martikainen, P., Silvola, J., \& Oenema, O. (1997). Greenhouse gas emissions from farmed organic soils: a review. Soil Use Management, 13, 245-250. http://dx.doi.org/10.1111/j.1475-2743.1997.tb00595.x

Kløve, B., Sveistrup, T. E., \& Hauge, A. (2010) Leaching of nutrients and emission of greenhouse gases from peatland cultivation at Bodin, Northern Norway. Geoderma, 154, 219-232. http://dx.doi.org/10.1016/j.geoderma.2009.08.022

Kuzyakov, Y. (2006). Sources of $\mathrm{CO}_{2}$ efflux from soil and review of partitioning methods. Soil Biology and Biochemistry, 38, 425-448. http://dx.doi.org/10.1016/j.soilbio.2005.08.020

Lim, E. T. (1991). Physical analysis: Determination of bulk density. In: Peat soils of Sarawak and the analytical methods (pp. 27-28). Malaysia: Department of Agriculture Sarawak.

Malaysian Agricultural Research and Development Institute (1996). Master Plan for Malaysian Agricultural Research and Development Institute Sessang Peat Research Station (pp. 34-67). Malaysia: MARDI.

Mohammed Selamat, M. (1996). Biologi tanaman dan keperluan persekitaran. In: Mohammed Selamat M. (Ed.), Penanaman Nanas - Nanas makan segar dan nanas kaleng (pp. 7-16). Malaysia: MARDI.

Mohammed Selamat, M., \& Abdul, Rahman, H. (1996). Amalan kultur. In: Mohammed Selamat M. (Ed.), Penanaman Nanas - Nanas makan segar dan nanas kaleng (pp. 24-34). Malaysia: MARDI.

Moore, T. R., \& Dalva, M. (1993). The influence of temperature and water table position on carbon dioxide and methane from laboratory column of peatland soils. Journal of Soil Science, 44, 651-644. http://dx.doi.org/10.1111/j.1365-2389.1993.tb02330.x

Murtedza, M., Padmanabhan, E., Mei, B. L. H., \& Siong, W. B. (2002). The peat soils of Sarawak. Strapeat Status Report (pp. 2-16). Malaysia: STRAPEAT.

Nelson, D. W., \& Sommers, L. E. (1982). Total carbon, organic carbon and organic matter. In: Page A.L., Miller R.H. \& Keeney D.R. (Eds.), Methods of soil analysis, Chemical and microbiological properties, Part 2 (pp. 570-571). Wisconsin: Soil Science Society of America.

Nyakanen, H., Alm, J., Lang, K., Silvola, T., \& Martikainen, P. J. (1995). Emission of $\mathrm{CH}_{4}, \mathrm{~N}_{2} \mathrm{O}$ and $\mathrm{CO}_{2}$ from a virgin fen drained for grassland in Finland. Journal of Biogeography, 22, 351-357. http://dx.doi.org/10.2307/2845930

Pandey, V. C., Singh, J. S., Singh, D. P., \& Singh, R. P. (2014). Methanotrophs: promising bacteria for environmental remediation. International Journal of Environment Science and Technology, 11, 241-250. http://dx.doi.org/10.1007/s13762-013-0387-9

Parmentier, F. J. W., van der Molen, M. K., de Jeu, R. A. M., Hendriks, D. M. D., \& Dolman, A. J. (2009). $\mathrm{CO}_{2}$ fluxes and evaporation on a peatland in the Netherlands appear not affected by water table fluctuations. Agricultural and Forest Meteorology, 149, 1201-1208. http://dx.doi.org/10.1016/j.agrformet.2008.11.007

Raziah, M. L. (2009). Scenario and prospect of Malaysia's pineapple industry. Economic and Technology Management Review, 4, 11-24.

Raziah, M. L., \& Alam, A. R. (2010). Status and impact of pineapple technology on mineral soil. Economic and Technology Management Review, 5, 11-19.

Sirin, A., \& Laine, J. (2012). Chapter 7: Peatlands and greenhouse gases. Retrieved 21 July, 2012, http://www.wetlands.or.id/PDF/chapter_7-9.pdf

STRAPEAT-Universiti Malaysia Sarawak-Natural Resource and Environment Board (2004). Physico-chemical characteristics. In: Handbook for Environmental Impact Assessment (EIA) of Development on Peatlands (pp. 3-7). Sarawak, Malaysia: UNIMAS.

Suhaimi, M., Emmyrafedziawati, K. R., Umi Kalsom, M. S., Sahilah, A. M., \& Ismail, A. B. (2007). Effect of 
land-clearing methods on distribution of microbial populations in peat ecosystem. In: Ismail A.B., Ong H.K., Mohamad Hanif M.J. \& Umi Kalsom M.S. (Eds.), A case study at MARDI Peat Research Station, Sessang, Sarawak, Malaysia (pp. 81-87). Malaysia: MARDI.

Toyota, K., Ritz, K., \& Young, I. M. (1996). Survival of bacterial and fungal populations following chloroform-fumigation: effects of soil matric potential and bulk density. Soil Biology and Biochemistry, 28, 1545-1547. http://dx.doi.org/10.1016/S0038-0717(96)00162-9

Wang, B., Hou, L., Liu, W., \& Wang, Z. (2013). Non-microbial methane emissions from soils. Atmospheric Environment, 80, 290-298. http://dx.doi.org/10.1016/j.atmosenv.2013.08.010

Watanabe, A., Purwanto, B. H., Ando, H., Kakuda, K., \& Jong, F. S. (2009). Methane and $\mathrm{CO}_{2}$ fluxes from an Indonesian peatland used for sago palm (Metroxylon sagu Rottb.) cultivation: Effects of fertilizer and groundwater level management. Agriculture, Ecosystem and Environment, 134, 14-18. http://dx.doi.org/10.1016/j.agee.2009.06.015

Widen, B., \& Lindroth, A. (2003). A calibration system for soil carbon dioxide-efflux measurement chambers. Soil Science Society of America Journal, 67, 327-334.

Zelles, L., Palojärvi, A., Kandeler, E., Von Lützow, M., Winter, K., \& Bai, Q. Y. (1997). Changes in soil microbial properties and phospholipids fatty acid fractions after chloroform fumigation. Soil Biology and Biochemistry, 29(9-10), 1325-1336. http://dx.doi.org/10.1016/s0038-0717(97)00062-x

Zhang, X., \& Jiang, H. (2014). Spatial variation in methane emissions from natural wetlands in China. International Journal of Environmental Science and Technology, 11, 77-86. http://dx.doi.org/10.1007/s13762-013-0385-y

Zulfikar, M. A., Novita, E., Hertadi, R., \& Djajanti, S. D. (2013). Removal of humic acid from peat water using untreated powdered eggshell as a low cost adsorbent. International Journal of Environmental Science and Technology, 10, 1357-1366. http://dx.doi.org/10.1007/s13762-013-0204-5

Zulkefli, M., Lim, Kim, Choo, L. N., \& Ismail, A. B. (2010). Soil $\mathrm{CO}_{2}$ flux from tropical peatland under different land clearing techniques. Journal of Tropical Agriculture and Food Science, 38(1), 131-137.

\section{Copyrights}

Copyright for this article is retained by the author(s), with first publication rights granted to the journal.

This is an open-access article distributed under the terms and conditions of the Creative Commons Attribution license (http://creativecommons.org/licenses/by/3.0/). 